\title{
TSLP wt Allele
}

National Cancer Institute

\section{Source}

National Cancer Institute. TSLP wt Allele. NCI Thesaurus. Code C50960.

Human TSLP wild-type allele is located in the vicinity of $5 q 22.1$ and is approximately $5 \mathrm{~kb}$ in length. This allele, which encodes thymic stromal lymphopoietin protein, plays a role in hematopoiesis and chemotaxis. 